\title{
Responding to the Humanitarian Crisis of the Rohingya in Myanmar: A Comparison between the Role of State and NGOs
}

\author{
Ardli Johan Kusuma ${ }^{1, *}$, Firman Firman ${ }^{2}$, Ahmad Harakan ${ }^{3}$, M. Chairil Akbar Setiawan ${ }^{4}$, Dodi Faedlulloh ${ }^{5}$ and Komang \\ Jaka Ferdian 6 \\ ${ }^{1}$ Department of Political Science, Universitas Pembangunan Nasional Veteran Jakarta, Jakarta, Indonesia \\ 2 Department of Public Administration, Universitas 17 Agustus 1945 Jakarta, Jakarta, Indonesia \\ ${ }^{3}$ Department of Government Studies, Universitas Muhammadiyah Makassar, Makassar, Indonesia \\ ${ }^{4}$ Department of International Relations, Universitas Pembangunan Nasional Veteran Jakarta, Jakarta, Indonesia \\ ${ }^{5}$ Department of Public Administration, Universitas Lampung, Bandar Lampung, Indonesia \\ ${ }^{6}$ Departmen of Political Science, Universitas Bangka Belitung, Bangka Belitung, Indonesia
}

Corresponding author: ardli.johan@yahoo.com

Submitted: 15 July 2020 | In revised form: 18 February 2021 | Accepted: 7 June 2021 |

Published: 26 July 2021

\begin{abstract}
The present study discusses the role of NGOs in the efforts of the Indonesian Humanitarian Alliance for Myanmar (AKIM: Aliansi Kemanusian Indonesia Untuk Myanmar) to handle the humanitarian crisis experienced by Ethnic Rohingya groups in Myanmar in 2017. This phenomenon in Myanmar began to draw a lot of attention when the AKIM was able to contribute to the cause even though state actors and IGO attempts were blocked by the Myanmar government. In this case, NGOs were able to play a role outside the traditional structure of modern international relations that was inaccessible to state or international organizations (IGOs) or state governments. This phenomenon indicates that NGOs have more access to attempts to settle the humanitarian crisis being experienced by the ethnic Rohingya groups in Myanmar. This is notable because the Myanmar government has blocked the aid of other countries and IGOs and has denied the assistance offered by the United Nations. The qualitative method was used in this study, employing a case study model to observe the effects that occurred. During data collection researchers, used study documents, and then the data was processed through interpretive analytical techniques to draw conclusions and formulate a model for the study.
\end{abstract}

Keywords: Ethnic Rohingya; humanitarian crisis; NGOs; the pattern of modern international relations

\section{Introduction}

There have been many conflicts between ethnic groups since Myanmar became an independent country in 1948. One of the interethnic conflicts attracting the most attention from the international community is the conflict between the Rohingya (Muslim) ethnic group and the majority Rakhine (Buddhist) community. This conflict has made the Rohingyas victims in an extraordinary humanitarian crisis. Conflicts in the Rakhine region have continued to occur, and the Myanmar government has yet to develop a political policy to overcome the conflicts and reduce the violence experienced by the Ethnic Rohingya group. The conflict forced most of the Rohingya 
to flee to various other countries to save themselves [1].

Ethnic Rohingyas have experienced numerous discrimination and human rights violations. One example of this was a suppression event that took place in 1962 when General Ne Win executed a coup and seized control of the Myanmar government. Once in power, his regime immediately carried out military operations to attack the separatists from the Ethnic Rohingya group. One of the military operations launched in 1978, known as 'Operation Dragon King' (Naga Min), caused more than 200,000 Rohingyas to flee to Bangladesh as a result of violence, murder, and rape. The Bangladeshi government declared a protest against Myanmar over the influx of Rohingya refugees in their territory. In July 1978, the United Nations mediated discussions on the situation, and the Myanmar government agreed to accept Rohingya immigrants for the return of Rakhine and so on, based on information from Amnesty International. This occurred after various discriminatory actions, and the suppression of humanitarian rule carried out by the Myanmar military junta [2].

The Rohingya are not recognized as citizens of Myanmar and are thus under pressure from the ethnic majority in Myanmar, most of whom are Buddhist. The Buddhist and Muslim communities in Arakan could live in harmony during the pre-colonialism era. However, with the regime change that controlled Arakan, and the entry of British colonies in Myanmar which led to the emergence of a spirit of nationalism by the Myanmar people in general which was based on religious identity, the Rohingya began to be marginalized by identity. The regime change that occurred in 1962, at which time the ruling military mobilized extraordinary violence against the Rohingya ethnic group by raising the issue of racism and xenophobia for political purposes, made the Rohingya ethnic identity look completely different from the majority Buddhist community of Myanmar. According to Arnab Roy Chowdhury, discrimination experienced by the Rohingya ethnicity is strongly influenced by striking differences in identity. The majority Buddhist Myanmar community considers that the Rohingya ethnic identity and religious identity are closer to the people of Bangladesh [3].

Understanding the history of the origins of the Rohingya ethnicity also makes the position of the Rohingya ethnic groups often getting into trouble among Myanmar's majority society. The Rohingya people claim that they have occupied the Arakan area long before the colonial era. They even claim that the Arakan region has been controlled by Muslim kings since the fifteenth century. This understanding then influences the different views historically between the majority community in Myanmar and the Rohingya ethnic community itself. Even this historical understanding has always taken an active role in the political dimension in Myanmar. Every regime in power cannot be separated from the issue of differences in identity and historical understanding inherent in the Rohingya ethnicity. Even a regime that is expected to be democratic under the leadership of Aung San Suu Kyi, who won the 2012 election with his Na- tional League for Democracy (NLD) party, cannot escape the issue of identity and history of the Rohingya ethnicity. The political interests of the elite put the Rohingya in no place for politicians in Myanmar to fight for [4]. The issue of identity and historical understanding maintained by the ruling regimes in Myanmar triggered large-scale human rights violations experienced by the Rohingya ethnic group in Myanmar. This condition is one of the reasons that most Rohingya seek asylum and become refugees in other countries. Their struggle to save themselves from the violence experienced in Myanmar raises new problems, especially for the countries to which they are aiming to flee, particularly Bangladesh, which is the main place the Rohingya have been seeking protection [5]. The Bangladeshi government faces a dilemma when dealing with refugees from Myanmar. For now, the Rohingya can be seen as refugees who must be given humanitarian assistance, but for the Bangladesh government, in the long run, the Rohingya will become a source of conflict [6]. These conditions make it increasingly difficult for Ethnic Rohingya groups in their efforts to fight for their own human rights.

The current Ethnic Rohingya status is stateless, and therefore they have no national protection or rights as legal citizens in Myanmar or in any other country. This violates the general concept of human rights, especially in relation to the concept of the International Bill of Human Rights (the Universal Declaration of Human Rights), especially Articles 13,14 , and 15. These describe a person's right to obtain citizenship status and protection from oppression. Article 13, Paragraphs 1 and 2, confirms these rights, explaining the following: (1) Everyone has the right to freedom of movement and residence within the borders of each state, and (2) Everyone has the right to leave any country, including his own, and to return to his country. Similarly, Article 14, Paragraphs 1 and 2 say this: (1) Everyone has the right to seek and to enjoy asylum from persecution in other countries. (2) This right may not be invoked in the case of prosecutions genuinely arising from non-political crimes or acts contrary to the purposes and principles of the United Nations. Next, Article 15, Verses 1 and 2 presents these ideas: (1) Everyone has the right to a nationality. (2) No one shall be arbitrarily deprived of his nationality nor denied the right to change his nationality [7]. The Ethnic Rohingyaity's right to have a clear citizenship status has been taken away despite their having lived in Myanmar for centuries. All forms of discrimination and violence experienced by ethnic Rohingya in Myanmar are violations of human rights. Acknowledgment of human rights is stated in the Universal Declaration of Human Rights, especially Articles 3, 5, and 18. Article 3 reads as follows: Everyone has the right to life, liberty, and security of person. Then article 5 which reads: No one shall be subjected to torture or cruel, inhuman or degrading treatment or punishment. And next is article 18 which reads: Everyone has the right to freedom of thought, conscience, and religion; this right includes freedom to change his religion or belief, and freedom, either alone or in community with others and in public or private, to manifest his religion 
or belief in teaching, practice, worship, and observance [7].

The articles of the Universal Declaration of Human Rights, clearly proclaim protection for human beings from all forms of persecution and acts of violence. In addition, they guarantee a sense of security and freedom of religion. Notably, this Declaration is explicitly adopted to define the meaning of the terms' fundamental freedom' and 'human rights' as they appear in the UN Charter, which is binding for all member states. For this reason, the Universal Declaration is a fundamental constitutive document of the United Nations. Besides, many international lawyers have argued that the Declaration is part of customary international law. Thus, it is a powerful tool in applying diplomatic and moral pressure to governments violating the contents of the articles of the Declaration. In 1968 at the International Conference on Human Rights, the United Nations suggested that the Declaration 'is an obligation for the members of the international community', and applies to all people. Therefore, Myanmar has violated this Declaration, which should apply to the entire international community without exception [8].

Some of the Ethnic Rohingya communities have attempted to survive in Myanmar, even though they experience pressure and violence both from the military and from the Rakhine (Buddhist) community. In August 2017, hundreds of Rohingya died because they experienced violence from the Myanmar military. This outbreak of conflict between the Ethnic Rohingya community and the Myanmar military further exacerbated the conditions of the Rohingya who remained in Rakhine. This phenomenon attracted the attention of the international community, inciting a desire to provide humanitarian assistance to the victims. Ethnic Rohingya experienced an extraordinary humanitarian crisis at that time. During this humanitarian crisis, the Myanmar government closed all access to outside assistance aimed at the Ethnic Rohingya group, who were experiencing hunger and were in dire need of such assistance.

The Indonesian government took a stand for giving sympathy to the Ethnic Rohingya groups, even deciding in 2015 to accept Myanmar refugees after being pressured by the majority of the people in Indonesia [9]. Indonesian people who are predominantly Muslim gave support and condemned the actions taken by the Myanmar government and the majority of the Buddhist community in Rakhine. However, the Indonesian government cannot change Myanmar's closing access to humanitarian aid to Rohingyas. Even humanitarian assistance from the UN cannot be channeled due to a blockade from the Myanmar government [10]. In 2017, the Indonesian government formed AKIM (the Indonesian Humanitarian Alliance for Myanmar), which consists of 11 humanitarian NGOs in Indonesia. Humanitarian assistance, which comes from both the government and civil society donations, can be channeled by AKIM to the Ethnic Rohingya group in Myanmar through collaboration with local NGOs from Myanmar.

\section{Research Method}

This study used a descriptive and analytic framework within the broader framework of a qualitative research model. According to John W. Creswell, qualitative research is a method for exploring and understanding the meaning that some individuals or groups of people think come from social or humanitarian problems [11]. Meanwhile, in this study, the authors chose a case study research strategy within a broad framework of qualitative research. Where, according to Stake, a case study is a research strategy in which researchers carefully investigate a program, event, activity, process, or group of individuals. Cases are limited by time and activity, and researchers collect complete information using various data collection procedures based on a predetermined time [12].

In the data collection process, the writer uses written secondary data. Or this method is often known as the "library research" method, where the author collects data to support the argument by collecting data from various sources such as written reports, books or literature, journals, newspapers, magazines, or data. data sourced from the internet. Besides, the author also interviewed one of the NGO leaders who was a member of AKIM. From the data that has been obtained, the author selects data, where the information obtained, will be taken only from sources deemed to have good validity.

Regarding data analysis, the author uses an understanding according to John W Creswell, which states that data analysis is a continuous process that requires continuous reflection on data, asks analytical questions, and writes short notes throughout the study [11]. Then Creswell added that there are steps that must be taken in the process of data analysis and interpretation. Among them: (1) processing and preparing data. In this case, the author prepares the data that has been obtained, both data obtained from the results of literature studies, or data obtained from interviews. (2) read the entire data. At this stage, the writer will read and understand the general idea of the data that has been obtained. (3) analyzing data. At this stage, the authors conducted an in-depth analysis of the data. Besides, the authors also interpret or interpret the collected data in the form of text or images.

This paper will describe the role of NGOs in handling the humanitarian crisis experienced by the Ethnic Rohingya group in Myanmar in 2017. Furthermore, this paper will provide an analysis of the limited roles of the state and IGOs in handling this humanitarian crisis. In this case, the role of NGOs is more significant than that of other countries or IGOs. This study used an inductive approach, in which the main objective was to create a model illustrating the role of NGOs in a modern international relations scheme. This revealed that in some instances, the roles of the state and IGOs are limited, and NGOs can provide aid in carrying out this work. 


\section{Frame of Analysis}

The inclusion of NGOs in handling humanitarian crises is not new. Margaret E. Keck and Kathryn Sikkink created a boomerang pattern (boomerang effect). In this model, NGOs can aid in suppressing a country when that country is considered to have violated an international norm. These authors further explained that when a country acts in violation of international norms, the role of NGOs is to disseminate information to the international community, as well as to gain support from other countries or intergovernmental organizations (IGOs). Following these efforts, other countries and IGOs will press the country in question to reinstate international norms [13] (Figure 1).

Furthermore, the role of NGOs in the enforcement of human rights norms in the era of globalization is inevitable.
NGOs have become some of the more important actors in these matters beyond the state that influences the implementation of specific human rights values. NGOs, which are representative of their communities, can penetrate national borders and take actions that cannot be carried out by the state. Some of the efforts of NGOs to enforce human rights norms include conducting human rights education; monitoring, investigating, and documenting human rights; setting standards and procedures, advocating and lobbying; and encouraging the process of democratization and development [14]. State actors cannot execute these activities under certain conditions (such as the case of the Rohingya in Myanmar); for instance, the case discussed here excludes other state actors because it involves the sovereignty of Myanmar itself.

Model Boomerang pattern

Margaret E. Keck and Kathryn Sikkink

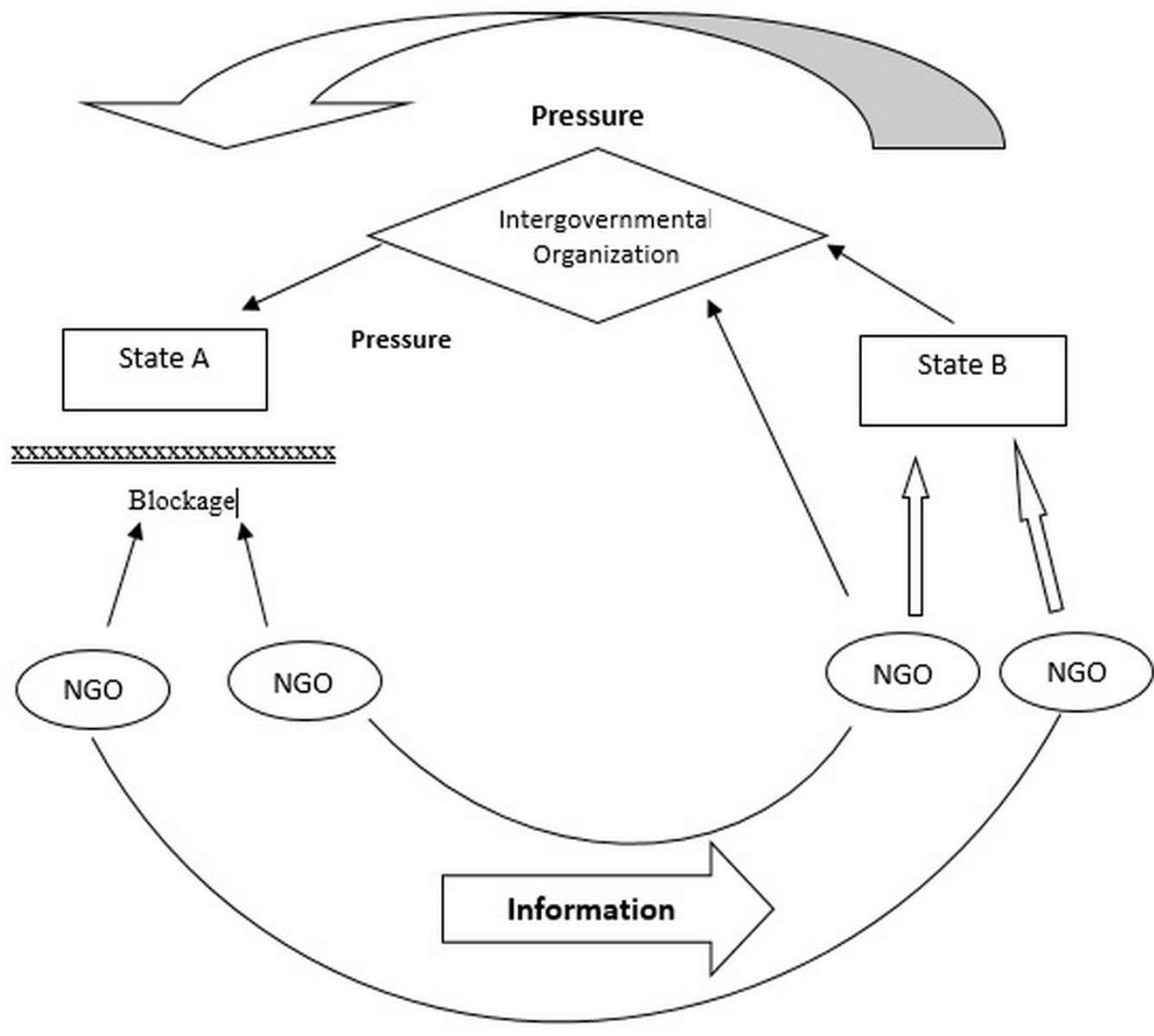

Figure 1. Boomerang pattern (boomerang effect): State $A$ blocks redress to organizations within it; they activate the network, whose members pressure their states and (if relevant) a third-party organization, which in turn pressure State $\mathrm{A}$ [15]. 
Notably, in the humanitarian crisis in Myanmar, the Indonesian NGO (AKIM) has been able to contribute where the Myanmar government blocks state actors and IGOs. In this case, modern international relations allow NGOs to play a role that cannot be performed by the state or international organizations or among other state governments. The role of the AKIM in the case of the humanitarian crisis in Myan- mar can be illustrated through the following model (Figure 2). This phenomenon follows the arguments put forward by Nikolai Holm that state that to increase the security level of a community, local actors are key. That is, local actors can become effective agents to improve human security by developing their abilities from external support [16].

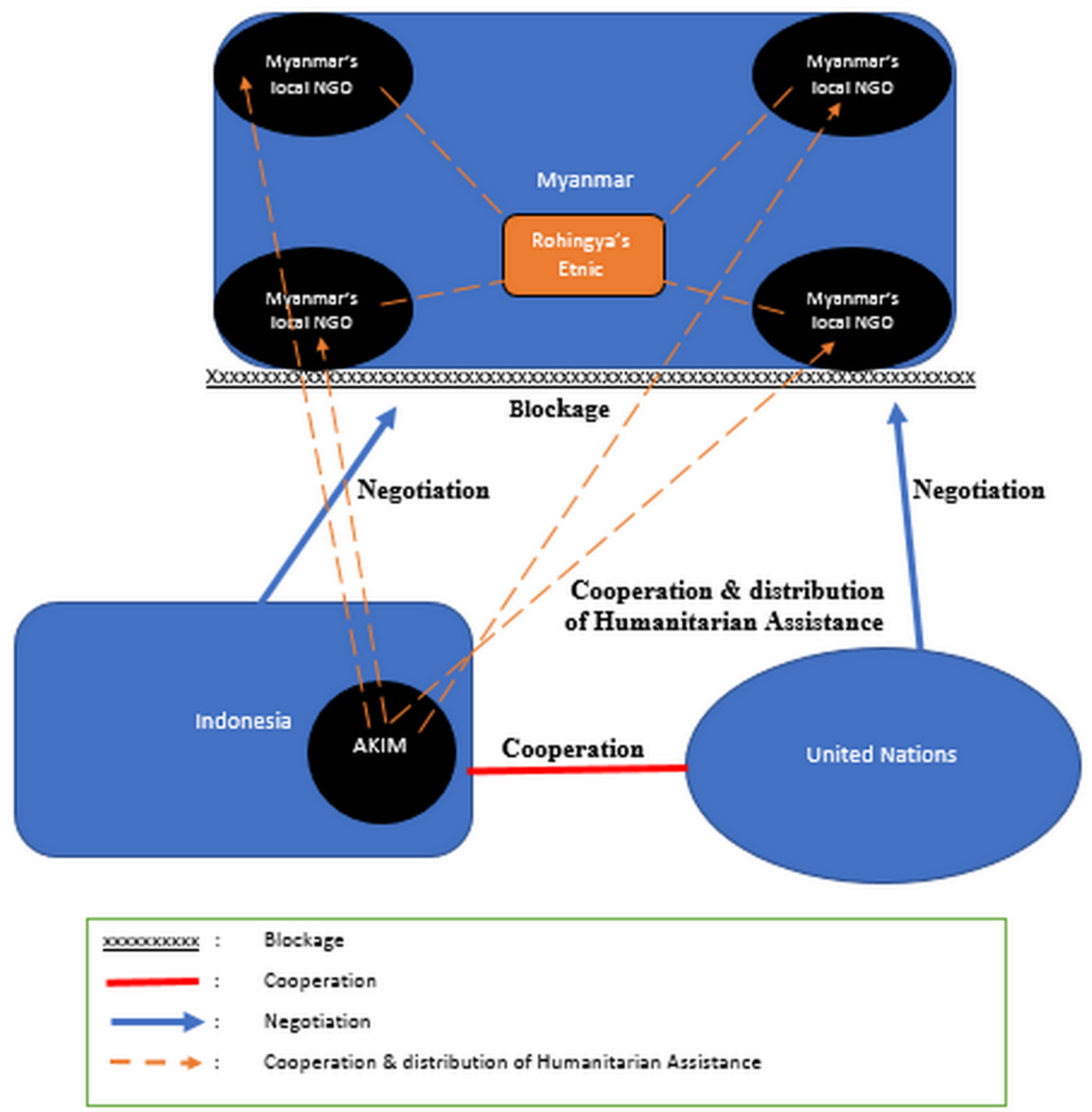

Figure 2. The Role of the Indonesian Humanitarian Allience for Myanmar (AKIM) in Handling the Rohingya Ethnic Humanitarian Crisis in Myanmar. 


\section{Results and Discussion}

4.1. The Role of the NGO AKIM (Indonesian Humanitarian Alliance for Myanmar) in Resolving the Ethnic Rohingya Humanitarian Crisis in Myanmar in 2017: An Analysis

The humanitarian crisis in Myanmar has become an international concern. One of the cases of human rights violations that has attracted global attention is related to the status of the Ethnic Rohingya who did not have citizenship; the group is stateless. The rejection of the Ethnic Rohingya as Myanmar citizens by the majority of the people and government of Myanmar is the main cause of the human rights violations inflicted on the Ethnic Rohingya. The striking differences in ethnicity and culture have collectively become the main weapon for the majority of people who reject the
Ethnic Rohingya in Myanmar. The differences in ethnicity and culture are supported by history, which reveals that the Rohingya are immigrants. For this reason, the Ethnic Rohingya identity differs from the ethnicities of most of the people in Myanmar, so the former are rejected as citizens of Myanmar [17].

In 2017, the violence experienced by the Rohingya people in Myanmar caused many casualties. In just one week, approximately 400 people were killed [18]. This dangerous situation created waves of refugees. The Ethnic Rohingya community chose to flee to save themselves from military operations carried out by the Myanmar government. In a single month, the number of Rohingya refugees from August to September 2017 reached 123,000 people [19]. Many refugees have fled Myanmar, as shown in the following is a graph of refugees from Myanmar from 1990 to 2017 (Figure 3).

\section{Refugee population by country or territory of origin}

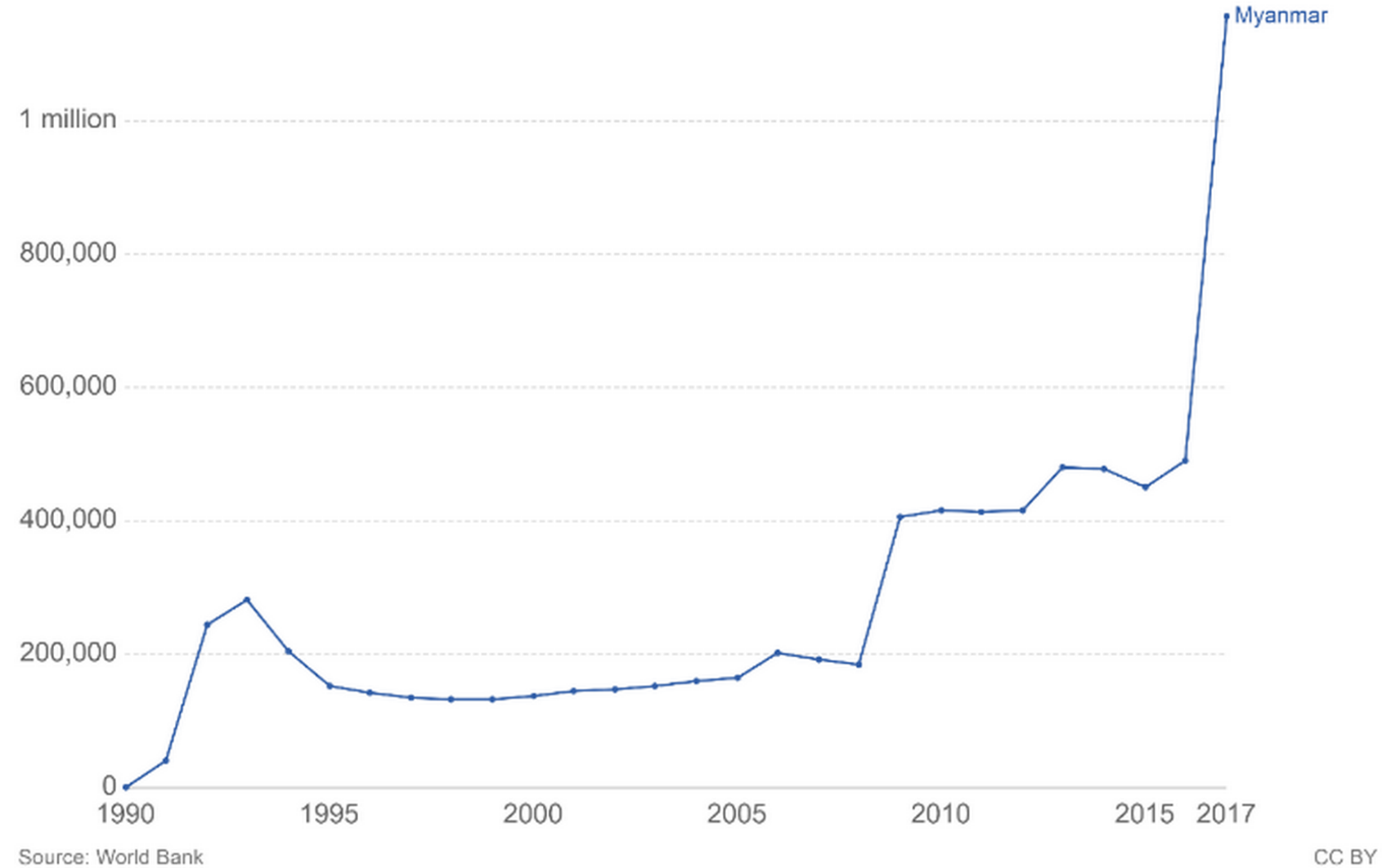

Figure 3. Number of refugees from Myanmar (1990-2017) [20]. 
The majority of Rohingya refugees have fled to Bangladesh, which directly borders Myanmar. Since Bangladesh was the leading destination for the 2017 evacuation, tensions rose between the Myanmar and Bangladesh governments regarding the status of Rohingya refugees, who were also considered burdens and threats to the future by the Bangladesh government. Diplomacy efforts have been attempted for years by the governments of Myanmar, Bangladesh, and other neighbouring countries. However, they have not had a significant impact on the humanitarian crisis experienced by the Ethnic Rohingya [21].

The majority of the international community sympathizes with the Rohingya people. For instance, the UN has called the Rohingya in Myanmar, the most persecuted minority in the world [22]. The discrimination, violence, murder, and expulsion that have made the Ethnic Rohingya stateless show that Myanmar has violated the Universal Declaration of Human Rights, which should apply to the entire international community without exception [8].

In Indonesia, both the community and the government have jointly stated that they reject the violence perpetrated by the Myanmar government that has caused this extraordinary humanitarian crisis. The conflicts that occurred in 2012, 2013, 2015, and 2017 resulted in many casualties in the Ethnic Rohingya group. Those who escaped death chose to flee, seeking asylum and becoming refugees in Myanmar's neighbouring countries, including Bangladesh, Thailand, Malaysia, and Indonesia. The emergence of refugees from Myanmar has created an extensive problem and raises issues at both the national and international levels. In Indonesia, the arrival of Rohingya refugees has attracted a great deal of attention. The Indonesian government has the dilemma of determining its attitude between deciding to accept the refugees and providing assistance to them or prohibiting the Rohingya refugees from entering Indonesian territory.

This struggle is evident in the responses of both the public and the government in Indonesia. On the one hand, the community was aided on May 10, 2015, by the Acehnese (majority Muslim), who assisted refugees floating in the ocean and enduring appalling conditions. A ship carrying 582 immigrants was found stranded in waters north of Aceh, and local fishermen then rescued it. The actions of the Acehnese fishermen received support from the majority of the Indonesian people. However, the TNI (Indonesia National Army) had the opposite reaction. On this subject, the chief of Indonesia's national army, General Moeldoko, said this: 'For the Rohingya people, when they cross the Malacca Strait and experience troubles at sea such as water or food deprivation, then they must be assisted. But if they enter our territory, then the TNI must protect its sovereignty' [23]. The government's attitude, however, was not without reason. Apart from the attitude of the $\mathrm{TNI}$, who want to maintain territorial sovereignty, Indonesia also feels it has no obligation to accept refugees. For instance, Indonesia was not one of the countries that ratified the 1951 Refugee Status convention. In addition, economic considerations and the potential for societal conflicts were the main reasons the Indonesian government initially rejected Rohingya refugees [23].

However, for humanitarian reasons, the majority of the Indonesian people think that their nation should provide assistance, allowing these refugees to enter Indonesian territory and provide them with aid and shelter. On the other hand, in May 2015, the government through the TNI insisted on protecting the nation's sovereignty by securing the border and prohibiting any foreigners from entering Indonesian territory, including the Rohingya refugees from Myanmar. This action of the Indonesian government triggered a heated debate among the public. The majority of Indonesians and the international community regretted the action taken by the Indonesian government, which initially did not allow Rohingya refugees to enter the country.

After holding a meeting with other countries who accept Rohingya refugees, such as Malaysia and Thailand, Indonesia finally agreed to accommodate them. Nevertheless, Indonesia set several prerequisites. One is that Rohingya refugees can stay temporarily in camps for one year. After one year, they will be sent home if the situation allows or if another country is willing to provide asylum to the Rohingya people. The handling of these refugees in Indonesia has been assisted by the United Nations High Commissioner For Refugees (UNHCR).

The issue of human rights violations experienced by Rohingya in Myanmar has become a national issue in Indonesia. The Indonesian people, who are predominantly Muslim, have carried out many peaceful marches in solidarity with the Ethnic Rohingya group, demanding the Myanmar government stop all forms of repression. The community has also demanded that the Indonesian government actively participate in finding the best solution to resolve the problem. Using humanitarian reasons, the Indonesian government has tried to approach the Myanmar government to deal with the crisis together. The Indonesian government offered a solution in the form of a $4+1$ formula related to the humanitarian crisis that occurred in Rakhine. The formula consists of four main points, namely the following: (1) restoring stability and security, (2) maximum restraint from using force, (3) protection for all people residing in Rakhine regardless of ethnicity and religion, and (4) the importance of opening immediate access to humanitarian aid. This formula also requires the implementation of the recommendation of the Advisory Commission Report for Rakhine led by Kofi Annan, which must be conducted as soon as possible [24].

Several NGOs working in the field of humanity have participated in handling the humanitarian crisis occurring in Myanmar. Humanitarian movements carried out by the people in Indonesia have been built through the collaboration of several humanitarian NGOs in Indonesia that work together with the Indonesian government it self. In addition, the Indonesian government, through the Foreign Ministry, formed the Indonesian Humanitarian Alliance for Myanmar (AKIM) [25]. AKIM is a body formed by the Indonesian government 
that is a combination of 11 NGOs engaged in the field of humanity that have been given the mandate to provide or channel aid to victims of the humanitarian crisis in Myanmar - in this case, the Rohingya. All forms of assistance from the Indonesian government or the people of Indonesia are channeled through AKIM.

The Chief Executive of AKIM Muhammad Ali Yusuf, said AKIM is a combination of eleven non-governmental organizations that have been active in humanitarian activities. He added that this alliance is a form of synergy between the government and the Indonesian people in helping to overcome the humanitarian crisis in Rakhine [26]. The idea to establish AKIM was sparked by several NGOs that are members of the Indonesian Humanitarian Forum (HFI), which is a forum for humanitarian non-governmental organizations to work together in dealing with humanitarian problems. Several HFI member NGOs consider that the handling of the humanitarian crisis of the Rohingya ethnics will be easier to respond to if several NGOs engaged in the humanitarian sector join a movement that focuses on responding to cases of Rohingya ethnicity in Myanmar. The idea is then in line with the offer from the government to give full support to all the efforts made by NGOs that will assist the Rohingya ethnic group in Myanmar. After that, it was only agreed to establish AKIM which was the result of a collaboration between several humanitarian NGOs and the Indonesian government [27]. The system of working relations between AKIM and the Indonesian government is collaborative. The Indonesian government only assists the lobbying process to the Myanmar government. Furthermore, AKIM member NGOs, which from the beginning already had funds collected from civil society donors, then distributed aid in collaboration with local NGOs from Myanmar [27].

The strategy used by the Indonesian government to assist victims of violence in Rakhine State, Myanmar, is based on recommendations issued by the Advisory Commission on Rakhine State led by Kofi Annan, which states that the International aid model for humanitarian issues must be participatory and inclusive [28,29]. The strategy to collaborate with several NGOs in Indonesia was chosen by the Indonesian government to establish a participatory and inclusive model of assistance to increase community awareness about the concept of human security.

Furthermore, the government established AKIM due to a blockade from the Myanmar government, which hampered the Indonesian government's attempts to assist the ethnic Rohingya. The Myanmar government stipulates that the distribution of aid to ethnic Rohingya should be done only with permission from the Myanmar government. However, when the UN has tried to give such assistance, all aid has been rejected by the Myanmar government on the grounds of unstable security. For this reason, Indonesia took a diplomatic approach with the Myanmar government, and in the end, both the Indonesian government was allowed to provide humanitarian aid as long as it aligned with the social institutions of Myanmar. For this reason, Indonesia formed AKIM, involving humanitarian NGOs from Indonesia to facilitate cooperation with NGOs in Myanmar [30,31].

The Indonesian government is well aware that the conflict between the Rohingyas and the population in Rakhine State which thus involves the Myanmar government is an internal problem for Myanmar. The Indonesian government does not have the right to interfere in Myanmar's internal affairs since it is a sovereign country. As nations that are both part of ASEAN countries, Indonesia and Myanmar have their own ways of conducting diplomatic relations, which must comply with the principles agreed upon by the ASEAN community. In the case of resolving the humanitarian crisis experienced by the Rohingya in Myanmar, the Indonesian government cannot do much to intervene, because these efforts would collide with the sovereignty of the Myanmar state. ASEAN countries have agreed to uphold a common fundamental principle called the 'ASEAN Way'. This principle contains provisions that ASEAN member countries must respect sovereignty and not interfere in the domestic affairs of other ASEAN member countries [32]. Through the 'ASEAN Way', Indonesia cannot directly pressure the Myanmar government in resolving its humanitarian crisis. Although the Indonesian government is constrained by this mechanism, however, the country still makes efforts toward resolving this ongoing humanitarian crisis. Indonesian Vice President Jusuf Kalla explained that the Indonesian state is a country in which the majority of the population is Muslim, so they should assist the Ethnic Rohingya groups who are victims of the conflict in Myanmar. Furthermore, he affirmed that this crisis is an international humanitarian problem, so there is a moral burden to help ethnic Rohingya [33].

Initially, the Indonesian government paid no attention to the plight of the Rohingyas. This was reflected when a wave of Rohingya refugees was barred from entering Indonesian territory by the Indonesian National Army (TNI) in 2015. At that time, these refugees were arriving in Indonesia by small boats, escaping from Myanmar to avoid the massacre, but when they reached Indonesian waters, the TNI immediately confronted them, prohibiting entry into Indonesian territory. However, fishers from the Province of Aceh, Indonesia felt sympathy for the nearly dead refugees and assisted the Rohingya, offering them temporary shelter in Aceh. Since then, the Indonesian people have urged the Indonesian government to open the blockade and grant the Rohingya refugees permission to enter Indonesian territory. Demonstrations have taken place in several regions, and the community has demanded that the Indonesian government find a solution to the crisis, simultaneously urging the Myanmar government to stop the slaughter of the Rohingyas [9].

In August 2017, there was a conflict between the Ethnic Rohingya group and the Myanmar military, and hundreds of Rohingyas were attacked by Myanmar military forces. This humanitarian crisis, which occurred in Rakhine, received international attention, and the UN became involved, consistently providing humanitarian assistance. However, when conflict broke out between the military and the Ethnic Rohingya community, the Myanmar government suddenly closed access to the Ethnic Rohingya settlement. Thus, 
all humanitarian assistance from the UN or other countries was blocked, so food supplies and other daily necessities could not be distributed. This blockade resulted from unstable security in the Rakhine region [10]. All external parties (including the United Nations) are now prohibited from entering the Rakhine region, which continues to be the primary site of conflict between the military and the Ethnic Rohingya group.

Being thus unable to distribute humanitarian assistance, the Indonesian government took a different approach, attempting diplomacy with the Myanmar government. To this end, Indonesian Foreign Minister Retno Lestari Priansari Marsudi successfully met with Aung San Suu Kyi and Military Commander General U Min Aung Hlaing. The Myanmar government accepted only representatives of the Indonesian government, and Myanmar refused to meet with envoys from any other country that wanted to similarly address the humanitarian crisis in Rakhine. Even Aung San Suu Kyi was not willing to meet with Malaysia's foreign minister, Anifah Aman when both attended the ASEAN Foreign Minister's Summit. Myanmar accepts representatives of the Indonesian government because the Indonesian government has used a humanitarian diplomacy approach to the crisis, not discrediting the Myanmar government, which other countries have done. However, the negotiations between Indonesia and Myanmar failed to open the blockade to receiving outside aid for the Rohingya. Thus, Myanmar remains closed to the attempts of other countries (as well as the UN) to distribute humanitarian aid. Instead, Myanmar decided that aid could be channeled only through local NGOs [34].

In response to this policy, the Indonesian government formed AKIM, which, again, consists of 11 NGOs with the mandate to provide and channel aid by establishing cooperation with NGOs in Myanmar [30]. These Indonesian NGOs that comprise AKIM are listed in the following table (Table 1).

Table 1. Indonesian Humanitarian Institutions Comprising AKIM

\begin{tabular}{|c|c|}
\hline Number & Institution \\
\hline 1. & Muhammadiyah Disaster Management Centre (MDMC) \\
\hline 2. & $\begin{array}{l}\text { The Institute for Disaster Management and Climate Change } \\
\text { (Lembaga Penanggulangan Bencana dan Perubahan Iklim - } \\
\text { Nahdlatul Ulama) }\end{array}$ \\
\hline 3. & PKPU Human Initiative \\
\hline 4. & Dhuafa Wallet (DompetDhuafa) \\
\hline 5. & Zakat House (Rumah Zakat) \\
\hline 6. & $\begin{array}{l}\text { The Caring Wallet For Ummah (Dompet Peduli Ummat- Daarut } \\
\text { Tauhiid) }\end{array}$ \\
\hline 7. & LAZIS Wahdah \\
\hline 8. & Infaq Management Institute (Laznas Lembaga Manajemen Infaq) \\
\hline 9. & Fast Action Response (Aksi Cepat Tanggap) \\
\hline 10. & $\begin{array}{l}\text { Lazis Dewan Da'wah Islamiyah Indonesia (Indonesian Lazis } \\
\text { Islamic Council of Da'wah) }\end{array}$ \\
\hline 11. & Social Trust Fund - UIN Jakarta \\
\hline
\end{tabular}

AKIM has several assistance programs whose primary focus is covering the fundamental needs of the Rohingya people affected by the conflict. The focuses include the fields of health, education, economics, and necessary assistance. AKIM distributes aid to the Ethnic Rohingya group in stages, with a grant of approximately 26 billion rupiahs. All aid distributed by AKIM is not only given to Ethnic Rohingyaities in Myanmar but also to Rohingya refugees who are displaced in Bangladesh [35].

As an NGO, AKIM does not have the power that a state possesses. The strategy used by AKIM in channeling aid to the Ethnic Rohingya group in Myanmar is different from what is done by countries. However, the identity of NGOs, which is identical to that of civil society, has proved more powerful and acceptable in Myanmar. Networking with local NGOs is advantageous for AKIM in the process of distributing humanitarian assistance, though this process is far from smooth. Obstacles faced by AKIM include poor infrastructure that impedes access to the distribution of aid, rejection from residents, and challenges from local authorities [36].

To deal with these obstacles, AKIM and the Indonesian government have approached the Myanmar government and local authorities to request permission to channel assistance. In addition, AKIM also cooperates with local NGOs to facilitate the distribution of aid and to make diplomacy easier for local authorities. Beyond this, AKIM always coordinates with the ICRC, an international humanitarian agency with branches in Myanmar [35]. Furthermore, AKIM and the ICRC approached the local community to ensure that the assistance was not given to only the Ethnic Rohingya group but also to the Hindu and Buddhist communities affected by the conflict in Rakhine. This would allow the local community to open access to distribute assistance [37].

By using the identity of NGOs and civil society movements, AKIM can enter and distribute humanitarian assistance to the Ethnic Rohingya groups in Myanmar, which previously could not be done by the state (including Indonesia). At that point, even the UN was blocked by the Myanmar government. Despite all the aforementioned obstacles, AKIM can perform a role unavailable to the state in the context of handling the humanitarian crisis in Myanmar. The initial priority of AKIM was to channel humanitarian assistance because the Rohingya ethical community in Myanmar desperately needed help.

The work of AKIM is subject to international law developed at the Convention on the Status of Refugees and the Protocol on the Status of Stateless Persons in 1951. Although Indonesia has not yet ratified such regulations, the role of NGOs in handling the problem of displacement was guaranteed at this Convention. At this conference, which was held from 2 to 25 July 1951, several recommendations were unanimously agreed upon by the participating countries. One of these, detailed in Point $\mathrm{C}$, describes the involvement of nongovernmental organizations considered competent to contribute to handling refugee problems. This recommendation stresses that states must provide support to non-governmental organizations that are committed to participating in resolving refugee problems [38]. 
The conflict in Myanmar has caused the Ethnic Rohingya group to have experienced insecurity in several fields related to the basic concept of human security. These include the following seven types of security: economic, food, health, environmental, personal, community, and political [39]. More specifically, the poverty experienced by the Rohingya due to economic discrimination has made their living conditions even worse, and the urgency of all of these threats are exacerbated by shortages of food and healthcare, fundamental to human existence. These conditions have led to severe malnutrition and even starvation. Obviously, all of these factors have a direct impact on the health quality of the Rohingya in Myanmar [40].

For this reason, short-term solutions are needed to overcome urgent problems, and long-term solutions must address this humanitarian problem as a whole. In the short term, the work of non-governmental organizations such as AKIM has provided immediate, tangible assistance to save the Rohingya from food and health crises. In the long term, however, large-scale political efforts must be made by the international community, both in the ASEAN region and globally, to push for more dialogue with the Myanmar government. At the same time, there must be efforts to demand wider democratization in Myanmar while promoting more critical awareness to avoid escalated conflict against the Rohingya community. One of the problems that have occurred in Myanmar is the difficulty in opening a democratic space. The military junta, which has been in power for a long time, inherits an "anti-democratic" political character. So that awareness of human rights values is difficult to develop in Myanmar. When the problem of discrimination against the Rohingya ethnicity has not found a solution, the situation is made worse by the military coup that took place on February 1, 2021.

The leader of the National League for Democracy (NLD) party, Aung San Suu Kyi, was arrested by the military. Apart from Suu Kyi, President Win Myint was also a prisoner of the military. After the incident, the military then issued a statement that they would rule the government and declare a state of emergency for the next year. The coup was allegedly the result of the military's dissatisfaction with the election results in November 2020. They alleged that the election results were manipulative and they did not want to admit it. However, the election commission and the winning party (NLD) rejected the allegations and stated that the results of the November 2020 election were following procedures [41]. With the military coup, there was a greater challenge to efforts to resolve the problems faced by the Rohingya ethnic group. In this regard, the international community must use all its efforts for the democratic process in Myanmar in general and the settlement of the humanitarian crisis for the Rohingya ethnic group in particular.

\section{Conclusion}

The Rohingya in Myanmar have experienced discrimination and deprivation of their rights. These violations have included acts of violence, deprivation of citizenship, and death from the series of conflicts that have occurred. Moreover, many have had to flee to various other countries to save their own lives. This human rights crisis, exacerbated in 2017, has attracted the attention of the international community, including the Indonesian state and the United Nations. As an international organization, the UN is trying to provide humanitarian assistance to the Ethnic Rohingya community in Myanmar, and similar attempts have been made by the Indonesian government. This attention from the international community has arisen from a sense of injustice because the Rohingya have been deprived of their rights as human beings.

Many of these efforts to provide humanitarian assistance have been rejected by the Myanmar government. For security reasons, the Burmese government has been blocking such assistance from both neighbouring countries and the United Nations. For this reason, the Indonesian government formed the Indonesian Humanitarian Alliance for Myanmar (AKIM), which consists of 11 NGOs working in the humanitarian field. As an NGO itself, AKIM then networked with local NGOs in Myanmar to provide humanitarian assistance to the Ethnic Rohingya group. In this case, NGOs have a crucial role. Their impact is visibly significant, even exceeding the ability of the state, as shown by the efforts of AKIM toward resolving the humanitarian crisis in Myanmar.

Thus, NGOs such as AKIM have been able to provide humanitarian assistance to the Ethnic Rohingya group, but this is only a temporary solution. The real problem is deeply political. The crisis is bound to structural discrimination, particularly from the Myanmar government, who do not recognize the Rohingya as citizens of Myanmar, even though history had proved that they have lived there for hundreds of years, long before Myanmar became an independent country. A resolution to this crisis will take more serious actions and significant changes, potentially involving many other countries. The international community must therefore exert more pressure through diplomacy and dialogue with the Myanmar government to be more democratic and transparent.

To conclude, NGOs and the state both make important contributions to overcoming human rights violations. Both NGOs and the state have their respective functions, which ideally complement each other to restore justice in the long run. In the context of high politics, the state's role is crucial, whereas accelerating human development and providing immediate assistance is where NGOs would play their part.

There is a significant role shown by AKIM, if it is related to the Boomerang pattern as described by Margaret E. Keck and Kathryn Sikkink, then the phenomenon of AKIM's role in responding to the humanitarian crisis that occurred in Mynamar has provided novelty. If the Boomerang Pattern shows a prominent role for the state and IGO, S, then the AKIM phenomenon shows that INGO, S, in certain conditions such as what happened in the handling of the humanitarian crisis for the Rohingya ethnic group in Myanmar, can provide a very significant role for handling it in a way quickly over the humanitarian crisis that occurred in Myanmar. 


\section{Acknowledgments}

We would like to thank Universitas Pembangunan Nasional Veteran Jakarta, Universitas 17 Agustus 1945 Jakarta, Universitas Muhammadiyah Makassar, Universitas Lampung,

\section{References and Notes}

[1] Kipgen N. Conflict in Rakhine State in Myanmar: Rohingya Muslims' Conundrum. Journal of Muslim Minority Affairs. 2013;33(2):298-310. doi:10.1080/13602004.2013.810117.

[2] Mitzy Gl. Perlawanan Etnis Muslim Rohingya terhadap Kebijakan Diskriminatif Pemerintah Burma-Myanmar. 2014;1(2):153-164. doi:10.22146/globalsouth.28836.

[3] Chowdhury RA. An 'Un-imagined Community': The Entangled Genealogy of an Exclusivist Nationalism in Myanmar and the Rohingya Refugee Crisis. Social Identities. 2020;26(5):590-607. doi:10.1080/13504630.2020.1782731.

[4] Lee R. A Politician, Not an Icon: Aung San Suu Kyi's Silence on Myanmar's Muslim Rohingya. Islam and Christian-Muslim Relations. 2014;25(3):321-333. doi:10.1080/09596410.2014.913850.

[5] Parnini SN. The Crisis of the Rohingya as a Muslim Minority in Myanmar and Bilateral Relations with Bangladesh. Journal of Muslim Minority Affairs. 2013;33(2):281-297. doi:10.1080/13602004.2013.826453.

[6] Rahman U. The Rohingya Refugee: A Security Dilemma for Bangladesh. Journal of Immigrant and Refugee Studies. 2010;8(2):233-239. doi:10.1080/15562941003792135.

[7] United Nations. Universal Declaration of Human Rights. Available from: https://www.un.org/en/universal-declaration-human-rights.

[8] Kusuma AJ. The Issue of Human Rights Violation Towards Rohingnya Ethnic Group and the Role of International Community. In: Proceeding Of The International Seminar and Conference on Global Issues-The Golden Triangle (Indonesia-India-Tiongkok) Inter relations in Religion, Science, Culture, and Economic. vol. 12. Wahid Hasyim University; 2015. pp. 16-23. Available from: https: //publikasiilmiah.unwahas.ac.id/index.php/ISC/article/view/1268.

[9] Moy LY, Kusuma AJ. Latar Belakang Indonesia Menerima Pengungsi Rohingya Pada Tahun 2015 (Analisa Konstruktivis). Global Insight Journal. 2016;1(1):60-75. Available from: http://journal.uta45jakarta. ac.id/index.php/GIJ/article/view/755.

[10] Holmes O. Myanmar Blocks all UN Aid to Civilians at Heart of Rohingya Crisis. The Guardian. 2017 Sep 4; Available from: https://www.theguardian.com/world/2017/sep/04/myanmarblocks-all-un-aid-to-civilians-at-heart-of-rohingya-crisis.

[11] Creswell JW. Research Design: Qualitative, Quantitative and Mixed Methods Approaches. Fawaid A, editor. Pustaka Pelajar; 2010.

[12] Stake RE. The Art of Case Study Research. Sage; 1995.

[13] Sikkink K, Keck ME. Transnational Advocacy Networks in International and Regional Politics. International Social Science Journal. 1999;51(159):89-101. doi:10.1111/1468-2451.00179.

[14] Vaibhav G, Manoj KT. The Role of NGOs in the Enforcement of Human Rights: An Overview. The Indian Journal of Political Science. 2010;71(3):769-793. Available from: https://www.jstor.org/stable/ 42748408?seq $=1\left\{\#\right.$ \}page $\left\{\_\right.$scan $\{$_ $\}$tab $\left\{\_\right.$contents.

[15] Keck ME, Sikkink K. Activists beyond Borders: Advocacy Networks in International Politics. Cornell University Press; 1998. doi:10.7591/j.ctt5hh13f.

[16] Holm N. Local Actor Strategies for Achieving Human Security Functionings. Journal of Human Security. 2017;13(1):22-33. doi:10.12924/johs2017.13010022.

[17] CK A, CS R. Institutional Strategies of Identity Constructions and Exclusions: Exploring the State of Rohingya Muslims in Myanmar. Otoritas : Jurnal IImu Pemerintahan. 2018;8(2):82-97. doi:10.26618/ojip.v8i2.1231.

[18] Muhaimin. Korban Tewas Konflik Berdarah di Rakhine Hampir 400 Orang. Sindonews. 2017 Sep 1; Available from: https://international.sindonews.com/read/1235831/40/korbantewas-konflik-berdarah-di-rakhine-hampir-400-orang-1504249040.

[19] Konflik Myanmar: Pengungsi Rohingya membanjiri Bangladesh. and Universitas Bangka Belitung who have supported this research. We also want to thank Rahmawati Husein, Ph.D (vice chair of Muhammadiyah Disaster Management Center), who has been willing to be an interviewees to complete the data in this research.

BBC Indonesia. 2017 Sep 5; Available from: http://www.bbc.com/ indonesia/dunia-41160159.

[20] Refugee population by country or territory of origin, 1990 to 2017. Our World in Data. Available from: https: //ourworldindata.org/grapher/refugee-population-by-countryor-territory-of-origin?tab=chart\&time=1990..2017\&country=MMR.

[21] Parnini SN, Othman MR, Ghazali S. The Rohingya Refugee Crisis and Bangladesh-Myanmar Relations. Asian and Pacific Migration Journal. 2013;22(1):133-146. doi:10.1163/15718158-01901001.

[22] Mangku DGS. Kasus Pelanggaran HAM Etnis Rohingya: dalam Perspektif ASEAN. Jurnal Lex Specialis. 2015;(21):99-108. Available from: http://jih.unbari.ac.id/index.php/LEX\{_\}SPCIALIST/article/ view/52.

[23] Asril S. Panglima TNI Tolak Kapal Pengungsi Rohingya Masuk RI, tapi Bersedia Beri Bantuan. Kompas. 2015 Mai 5; Available from: https://nasional.kompas.com/read/2015/05/15/20213301/Panglima. TNI.Tolak.Kapal.Pengungsi.Rohingya.Masuk.RI.tapi.Bersedia.Beri. Bantuan.

[24] Pujayanti A. Indonesia dan Tragedi Kemanusiaan Rohingya. Majalah Info Singkat Hubungan Internasional. 2017;IX(17):5-8. Available from: http://berkas.dpr.go.id/puslit/files/info\{_\}singkat/InfoSingkat-IX17-I-P3DI-September-2017-179.pdf.

[25] Maulana V. Menlu Retno Luncurkan Aliansi Kemanusiaan Indonesia. sindonewscom. 2017 Aug 31; Available from: https://international.sindonews.com/read/1235597/40/menluretno-luncurkan-aliansi-kemanusiaan-indonesia-untuk-myanmar1504167196.

[26] Wardah F. Indonesia Launches Humanitarian Assistance Program for Myanmar. Available from: https://www.voaindonesia. com/a/indonesia-luncurkan-program-bantuan-kemanusiaan-bagimyanmar/4009802.html.

[27] Husein R. Personal Interview with the Deputy Chairperson of the Muhammadiyah Disaster Management Center (MDMC).

[28] Kementerian Luar Negeri Republik Indonesia. Komitmen Bantu Myanmar, Menlu Luncurkan Program Bantuan Kemanusiaan. Ministry of Foreign Affairs of the Republic of Indonesia; 2017. Available from: https://www.kemlu.go.id/id/berita/beritaperwakilan/Pages/Komitmen-Bantu-Myanmar,-Menlu-LuncurkanProgram-Bantuan-Kemanusiaan.aspx.

[29] Towards a Peaceful, Fair and Prosperous Future for the People of Rakhine; 2017. Available from: http://www.rakhinecommission.org/.

[30] Taufiqqurahman M. Kecuali dari Indonesia, Myanmar Tolak Bantuan untuk Etnis Rohingnya. detikNews. 2017 Sep 19; Available from: https://news.detik.com/berita/d-3649373/kecuali-dariindonesia-myanmar-tolak-bantuan-untuk-etnis-rohingnya.

[31] Maulana V. Myanmar Tolak Bantuan PBB untuk Rakhine. Sindonews. 2017 Sep 4; Available from: https://international.sindonews.com/ read/1236576/40/myanmar-tolak-bantuan-pbb-untuk-rakhine1504526620 .

[32] Bangun $\mathrm{BH}$. Tantangan ASEAN dalam Melakukan Penanganan Pengungsi Rohingya. 2017;4(3):569-587. doi:https://doi.org/10.22304/pjih.v4n3.a8.

[33] Purnomo NR. Jusuf Kalla Jelaskan Alasan Pemerintah RI Harus Bantu Selesaikan Konflik Rohingya - Tribunnews. Tribunnewscom. 2016 Dec 13; Available from: http: //www.tribunnews.com/nasional/2016/12/13/jusuf-kalla-jelaskanalasan-pemerintah-ri-harus-bantu-selesaikan-konflik-rohingya.

[34] Adi B. "Non Megaphone Diplomacy", cara ampuh Indonesia bantu warga Rohingya. Rappler. 2017 Sep 12; Available from: https://www.rappler.com/indonesia/berita/181963-rahasiaindonesia-mampu-tembus-myanmar.

[35] Rini RAP. AKIM Alokasikan Dana Rp 15 Miliar Untuk Bantu Pengungsi Rohingya Di Bangladesh. Tribunnewscom. 2017 Sep 9; Available from: https://www.tribunnews.com/nasional/2017/09/22/akim- 
alokasikan-dana-rp-15-miliar-untuk-bantu-pengungsi-rohingya-dibangladesh.

[36] Purnomo NR. Bantuan Dari Indonesia Untuk Myanmar Tidak Hanya Untuk Etnis Rohingya. tribunnews. 2017 Aug 31; Available from: https://www.tribunnews.com/nasional/2017/08/31/bantuandari-indonesia-untuk-myanmar-tidak-hanya-untuk-etnis-rohingya.

[37] Hasan RA. ICRC: Penyaluran Bantuan ke Rohingya Masih Banyak Kendala. Available from: https://www.liputan6.com/global/read/ 3354323/icrc-penyaluran-bantuan-ke-rohingya-masih-banyakkendala.

[38] Convention and Protocol Relating to the Status of Refugees. The United Nations High Commissioner for Refugees (UNHCR); 1967.
Available from: https://www.unhcr.org/id/wp-content/uploads/sites/ 42/2017/05/KonfensidanProtokol.pdf.

[39] Capie D, Evans P. Human Security. The Asia-Pacific Security Lexicon. 2018;pp. 135-144. doi:10.1355/9789812304971-022.

[40] Mahmood SS, Wroe E, Fuller A, Leaning J. The Rohingya People of Myanmar: Health, Human Rights, and Identity. The Lancet. 2017;389(10081):1841-1850. doi:10.1016/S0140-6736(16)00646-2.

[41] Aida NR. The Myanmar Coup, The Causes and What Actually Happened? Kompas. 2021 Feb 12; Available from: https://www.kompas.com/tren/read/2021/02/12/123000265/kudetamyanmar-sebab-dan-apa-yang-sebenarnya-terjadi- ?page=all. 